\title{
Communication
}

\section{Efficient enantioselective hydrogenation of quinolines catalyzed by conjugated microporous polymers with embedded chiral BINAP ligand}

\author{
Xu Wang a,b, Jun Li a, Shengmei Lu a, Yan Liu a,*, Can Li a,\# \\ a State Key Laboratory of Catalysis, Dalian Institute of Chemical Physics, Chinese Academy of Sciences, Dalian 116023, Liaoning China \\ b University of Chinese Academy of Sciences, Beijing 100049, China
}

\section{A R T I C L E I N F}

Article history:

Received 4 May 2015

Accepted 21 May 2015

Published 20 August 2015

Keywords:

Enantioselective hydrogenation

Quinoline

Polymer

BINAP

Isolation effect

\begin{abstract}
A B S T R A C T
Chiral Ir complexes were successfully used in the asymmetric hydrogenation of olefins, ketones, and quinolines. However, almost all the catalytic systems could not tolerate a high catalyst loading because of the formation of an irreversible iridium dimer and trimer during the reaction. It is expected that higher catalytic activity may be achieved if the Ir-complexes were isolated in space. The development of conjugated microporous polymers (CMPs) gives the opportunity for the spatial separation of the complexes. A series of chiral CMPs based on the chiral $(R)$-BINAP ligand (BINAP-CMPs) with different surface areas were synthesized. The BINAP ligands were separately distributed in the framework and were three times more active than the homogeneous catalyst (TOF $340 \mathrm{~h}^{-1}$ VS 100 $\mathrm{h}^{-1}$ ) for the asymmetric hydrogenation of quinolines.
\end{abstract}

(C) 2015, Dalian Institute of Chemical Physics, Chinese Academy of Sciences. Published by Elsevier B.V. All rights reserved.
The asymmetric hydrogenation of quinolines is one of the most convenient route to synthesize enantiomerically pure tetrahydroquinoline derivatives which are important organic synthetic intermediates and structural units of alkaloids and biologically active compounds [1]. The first successful homogeneous asymmetric hydrogenation of quinolines was described by Zhou and co-workers using a Ir catalytic system [2]. Quinolines with different substituents were investigated in their following works [3-7]. Chan's group subsequently described that the air-stable and recyclable Ir-P-Phos and Ir- diphosphinite are efficient catalysts for the asymmetric hydrogenation of quinolines [8-10]. Reetz and co-workers also found that BINOL-derived diphosphonites with achiral P-ligands as additive catalyzed the same reaction [11]. Despite these important advances, a problem in the reported reaction systems was that good results were only obtained at a low substrate-catalyst ratio. The problem with a high catalyst loading was attributed to the formation of an irreversible iridium dimer and trimer during the reaction which would be pathways for catalyst deactivation [12]. Therefore, developing a highly efficient catalytic system for the asymmetric hydrogenation of quinolines is still needed.

Several attempts to avoid iridium dimer formation were tried (Scheme 1). One method is the introduction of bulky substituents onto the chiral ligands to inhibit the formation of inactive dimmers and trimers, thus promoting the catalytic activity (Scheme 1.1). Fan's group synthesized a series of dendritic dendrimer $\mathrm{G}_{n}$ DenBINAP ligands by the condensation of the dendritic wedges $\mathrm{G}_{n}$ - $\mathrm{COOH}$ with $(S)$-5,5'-diamino BINAP $(S)$-1 [13]. The $\mathrm{G}_{n}$ DenBINAP ligands gave much higher catalytic ac-

\footnotetext{
* Corresponding author. Tel: +86-411-84379302; Fax: +86-411-84694447; E-mail: yanliu503@dicp.ac.cn

\# Corresponding author. Tel: +86-411-84379097; Fax: +86-411-84694447; E-mail: canli@dicp.ac.cn

This work was supported by the National Natural Science Foundation of China (21322202).

DOI: 10.1016/S1872-2067(15)60903-2 | http://www.sciencedirect.com/science/journal/18722067 | Chin. J. Catal., Vol. 36, No. 8, August 2015
} 


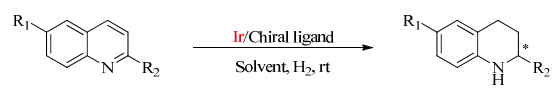

1. The reported strategies based on bulky substituents on ligands:

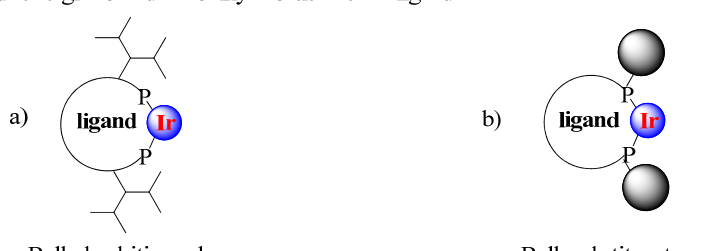

Bulk dendritic wedges

Bulk substituents

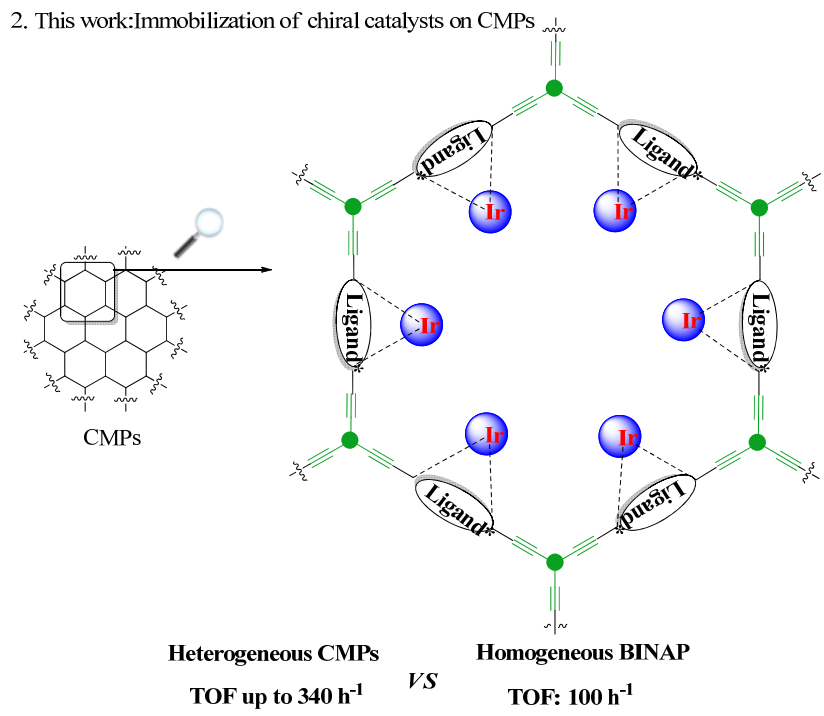

Scheme 1. Strategies for inhibiting the dimerization of the Ir-complex in the hydrogenation of quinolone.

tivity than BINAP through the steric shielding effect of the bulky dendritic wedges to reduce dimerization (Scheme 1.1(a)). Zhou and coworkers reported that introducing bulky groups onto the coordination phosphorus atoms effectively blocked the formation of inactive dimer and trimer species and improved the activity of the Ir catalysts [14] (Scheme 1.1(b)).

Recently, we reported the synthesis of a series of CMPs by embedding the chiral BINAP ligand into CMP networks. These solid materials are efficient catalysts for the asymmetric hydrogenation of $\beta$-keto esters [15]. Because all the BINAPs are embedded on the pore structure of the networks separately, we envisioned that these heterogeneous catalysts [16-18] with an inherent isolation effect can perform the asymmetric hydrogenation of quinoline with high activity through preventing the formation of dimers and trimers. (Scheme 1.2) Here, we reported the results.

A typical strategy for synthesizing BINAP-CMP-3D-2 was as follows: 1,3,5,7-Tetrakis(4-ethynylphenyl) adamantine, $(R)$ 4,4-DibromoBINAPO, tetrakis-(triphenylphosphine) palladium, and copper iodide were dissolved in a mixture of dioxane and $\mathrm{Et}_{3} \mathrm{~N}$. The reaction mixture was heated to $80{ }^{\circ} \mathrm{C}$ and stirred for $72 \mathrm{~h}$ under a nitrogen atmosphere. The precipitate was filtered and washed with solvent. After reducing with $\mathrm{HSiCl}_{3}$, BINAP-CMP-3D-2 was obtained.

We began by examining the hydrogenation of 2methylquinoline 1a with an iridium catalyst in the presence of different BINAP-CMPs. We were pleased to find that the hydrogenation catalyzed by the BINAP-CMPs proceeded smoothly and afforded the product with moderate enantioselectivity (Table 1, entries 1-4). In sharp contrast, the homogeneous hydrogenation catalyzed by BINAP gave trace product under same reaction conditions (Table 1, entry 5). Moreover, the catalytic activity gradually increased with increasing surface area and pore volume of the BINAP-CMPs. CMPs with larger surface area and pore volume benefit the diffusion of substrate and product, which makes it easier to access the active center and improve the activity.
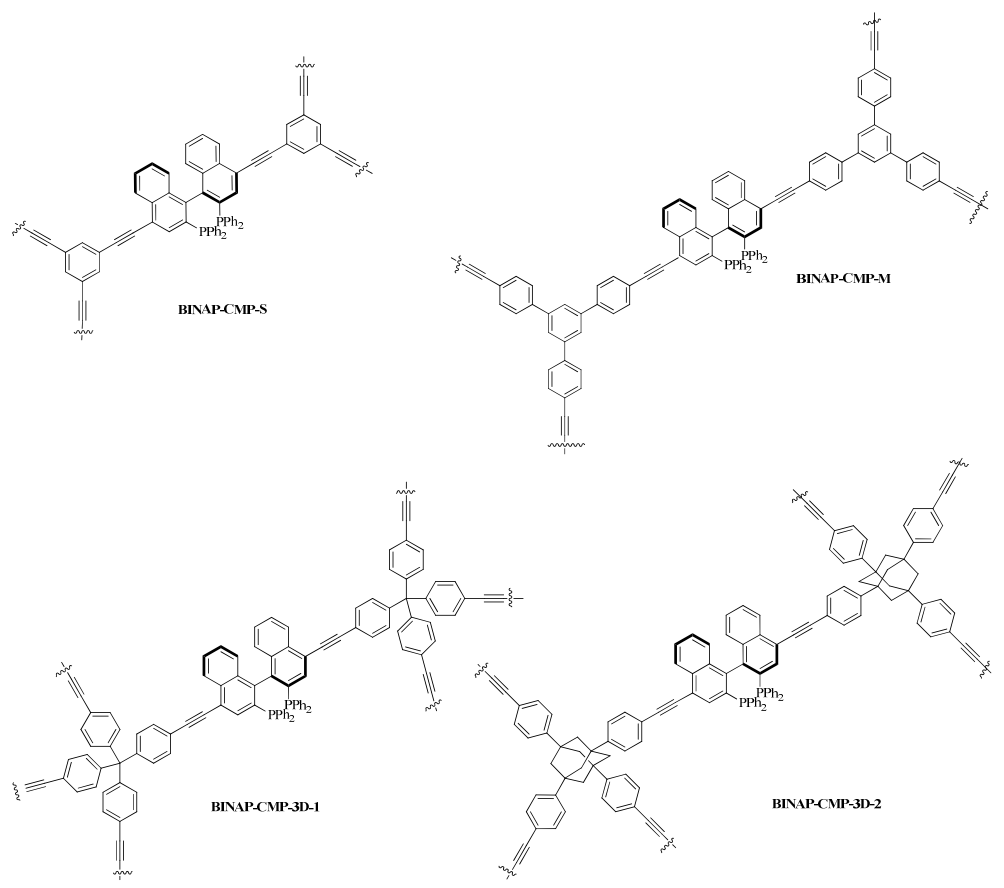

Scheme 2. Structure of BINAP-CMPs. 
Table 1

Comparison of catalytic activity of the synthesized BINAP-CMPs.

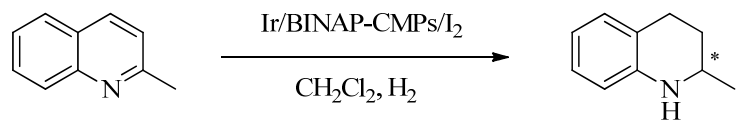

\begin{tabular}{lcccccc}
\hline Entry & BINAP-CMPs & $A_{\text {BET }^{\mathrm{a}}}\left(\mathrm{m}^{2} / \mathrm{g}\right)$ & $V_{\text {total }^{\mathrm{b}}}\left(\mathrm{cm}^{3} / \mathrm{g}\right)$ & Conversion $^{\mathrm{c}}(\%)$ & $\mathrm{TOF}^{\mathrm{d}}\left(\mathrm{h}^{-1}\right)$ & $\mathrm{ee}^{\mathrm{e}}(\%)$ \\
\hline 1 & BINAP-CMP-S & 170 & 0.37 & 9 & 180 & 48 \\
2 & BINAP-CMP-M & 318 & 0.46 & 10 & 200 & 50 \\
3 & BINAP-CMP-3D-1 & 279 & 0.76 & 12 & 240 \\
4 & BINAP-CMP-3D-2 & 398 & 0.77 & 17 & 340 & 54 \\
5 & BINAP & - & - & 5 & 100 & 70 \\
\hline
\end{tabular}

Reaction conditions: quinaldine $0.25 \mathrm{mmol}, \mathrm{CH}_{2} \mathrm{Cl}_{2} 3 \mathrm{~mL}$, $[\mathrm{Ir}(\mathrm{COD}) \mathrm{Cl}]_{2} 0.000125 \mathrm{mmol}, \mathrm{I}_{2} 0.05 \mathrm{mmol}, 1.5 \mathrm{MPa} \mathrm{H}_{2}, 25^{\circ} \mathrm{C}, 0.5 \mathrm{~h}$. a Surface area calculated from the $\mathrm{N}_{2}$ adsorption isotherm using the BET method. ${ }^{\mathrm{b}}$ Total pore volume at $\mathrm{p} / \mathrm{p}_{0}=0.99$. ${ }^{\mathrm{c}}$ Determined by ${ }^{1} \mathrm{H}$ NMR analysis of the crude product. ${ }^{\mathrm{d}}$ Average TOF over the reaction time. ${ }^{\mathrm{e}}$ Determined by HPLC analysis with a Chiralpak OJ-H column.

Table 2

Asymmetric hydrogenation of quinaldine (1a) catalyzed by the BINAP-CMP-3D-2 catalyst.

\begin{tabular}{|c|c|c|c|}
\hline Entry & Solvent & Conversion $^{\mathrm{a}}(\%)$ & $\mathrm{ee}^{\mathrm{b}}(\%)$ \\
\hline 1 & THF & 99 & 34 \\
\hline 2 & $\mathrm{CH}_{2} \mathrm{Cl}_{2}$ & 99 & 60 \\
\hline 3 & $\mathrm{MeOH}$ & 88 & 29 \\
\hline 4 & toluene & 99 & 40 \\
\hline 5 & benzene & 99 & 38 \\
\hline 6 & dioxane & 99 & 39 \\
\hline 7 & $\mathrm{CH}_{2} \mathrm{Cl}_{2} / \mathrm{THF} 1: 2$ & 99 & 56 \\
\hline 8 & $\mathrm{CH}_{2} \mathrm{Cl}_{2} /$ toluene $1: 2$ & 99 & 51 \\
\hline $9 \mathrm{c}, \mathrm{d}$ & $\mathrm{CH}_{2} \mathrm{Cl}_{2}$ & 99 & 69 \\
\hline $10^{\text {c,e }}$ & $\mathrm{CH}_{2} \mathrm{Cl}_{2}$ & 99 & 70 \\
\hline $11^{\mathrm{c}}$ & $\mathrm{CH}_{2} \mathrm{Cl}_{2}$ & 99 & 70 \\
\hline $12^{\mathrm{c}, \mathrm{f}}$ & $\mathrm{CH}_{2} \mathrm{Cl}_{2}$ & 93 & 70 \\
\hline $13^{c, g}$ & $\mathrm{CH}_{2} \mathrm{Cl}_{2}$ & 95 & 73 \\
\hline $14 \mathrm{c,h}$ & $\mathrm{CH}_{2} \mathrm{Cl}_{2}$ & 99 & 69 \\
\hline
\end{tabular}

Reaction conditions: quinaldine $0.25 \mathrm{mmol}, \mathrm{CH}_{2} \mathrm{Cl}_{2} 3 \mathrm{~mL}$, [ $\left.\mathrm{Ir}(\mathrm{COD}) \mathrm{Cl}\right]_{2}$ $0.000125 \mathrm{mmol}, \mathrm{I}_{2} 0.05 \mathrm{mmol}, 4 \mathrm{MPa} \mathrm{H}_{2}, 25{ }^{\circ} \mathrm{C}, 18 \mathrm{~h}$. a,b See Table 1. ${ }^{c}[\operatorname{Ir}(\mathrm{COD}) \mathrm{Cl}]_{2} 0.00125 \mathrm{mmol}, 2 \mathrm{~h} .{ }^{\mathrm{d}} 6.5 \mathrm{MPa} \mathrm{H}$. e $5 \mathrm{MPa} \mathrm{H}{ }_{2}{ }^{\text {f }} 1.5 \mathrm{MPa} \mathrm{H}$. g $0{ }^{\circ} \mathrm{C}$. ${ }^{\mathrm{h}} 50^{\circ} \mathrm{C}$.

To obtain higher enantioselectivity, the effects of the solvent, temperature and pressure were investigated by using BINAP-CMP-3D-2 as the catalyst (Table 2). A series of organic solvents were investigated. $\mathrm{CH}_{2} \mathrm{Cl}_{2}$ was the best in terms of both conversion and enantioselectivity (Table 2, entries 1-8). The enantioselectivity of the reaction was slightly increased at low temperature with incomplete conversion (Table 2, entry 13). Also, the reaction did not reach completion under a low pressure(Table 2 entry 12).

Using the optimized reaction conditions, the limit of catalyst activity was also investigated. The BINAP-CMP-3D-2 catalyst was found to be highly effective even at a high substrate/catalyst ratio although the enantioselectivity decreased with a low catalyst loading (Table 3).

Using the optimal conditions, we demonstrated the scope of quinoline for this heterogeneous hydrogenation (Table 4). All substituted quinolines used here were hydrogenated with good conversion and modest enantioselectivity. The reaction was relatively insensitive to the length of the 2-alkylated side chain
Table 3

Minimum amount of Ir/BINAP-CMP-3D-2 catalyst that can be used.<smiles>Cc1ccc2ccccc2n1</smiles>

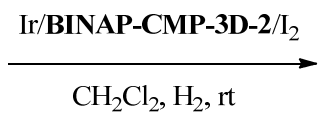<smiles>C[C@H]1CCc2ccccc2N1</smiles>

\begin{tabular}{lcccc}
\hline Entry & Time $(\mathrm{h})$ & Substrate/Catalyst & Conversion $^{\mathrm{a}}(\%)$ & $\mathrm{ee}^{\mathrm{b}}(\%)$ \\
\hline 1 & 2 & $100: 1$ & 99 & 70 \\
2 & 2 & $500: 1$ & 99 & 64 \\
3 & 2 & $1000: 1$ & 99 & 60 \\
$4^{\mathrm{d}}$ & 6 & $2000: 1$ & 99 & 53 \\
$5^{\mathrm{e}}$ & 24 & $5000: 1$ & 93 & 42 \\
\hline
\end{tabular}

Reaction conditions: quinaldine (1a) $0.25-5 \mathrm{mmol}, \mathrm{CH}_{2} \mathrm{Cl}_{2} 3 \mathrm{~mL}, \mathrm{I}_{2} 0.05$ mmol, $4 \mathrm{MPa} \mathrm{H}_{2}, 25^{\circ} \mathrm{C}$. a,b See Table 1.

of the quinoline. It was interesting that with increasing length of the side chain of $R_{2}$, the enantioselectivity obtained with BINAP-CMP-3D-2 increased from being slightly less than to be obviously higher than the enantioselectivity of the homogeneous Ir/BINAP catalyst (Table 4, entries 1-5). The conversion decreased with the increasing of steric hindrance (Table 4, entries 4-6), which may be due to that bulky substituted quinolines suffer more diffusion resistance when diffusing through the pore structure of the polymer. With 6-substituted quinolines as the substrate (Table 4, entries 7-9), low enantioselectivity with complete conversion were observed.

The recyclability of the BINAP-CMP-3D-2 catalyst was also investigated (Table 5). Upon completion of the reaction, the Ir/BINAP-CMP-3D-2 catalyst was easily recovered by centrifugation and a regular filter. The colorless filtrate from the asymmetric hydrogenation of quinaldine (1a) did not afford any additional product, showing the heterogeneous nature of the reaction system. After washing with $\mathrm{CH}_{2} \mathrm{Cl}_{2}$ and heating under vacuum, the solid catalyst was reused for the next cycle. We did not see any significant deterioration in the activity for the recovered catalyst even after five cycles.

In summary, we synthesized a series of BINAP-CMPs with different surface areas, which gave high activity and modest enantioselectivity in the Ir-catalyzed asymmetric hydrogenation of quinolines. The catalytic activity was related to the structural properties of the BINAP-CMPs. The CMP with a higher surface area and pore volume gave better asymmetric hydrogenation results. Through preventing the formation of 
Table 4

Catalytic asymmetric hydrogenation of quinoline derivatives.<smiles>[R]c1ccc2nc([R])ccc2c1</smiles>

1 (1a-1i)

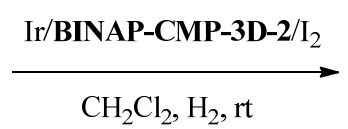

$\mathrm{CH}_{2} \mathrm{Cl}_{2}, \mathrm{H}_{2}, \mathrm{rt}$<smiles>[R][C]1CCc2cc([R])ccc2N1</smiles>

$2(2 a-2 i)$

\begin{tabular}{|c|c|c|c|c|c|c|}
\hline \multirow{2}{*}{ Entry } & \multirow{2}{*}{$\mathrm{R}_{1} / \mathrm{R}_{2}$ (substrates) } & \multicolumn{2}{|c|}{ Conversion a $(\%)$} & \multicolumn{2}{|c|}{$\mathrm{ee}^{\mathrm{b}}(\%)$} & \multirow{2}{*}{ Configuration ${ }^{\mathrm{C}}$} \\
\hline & & Ir/BINAP-CMP-3D-2 & Ir/BINAP & Ir/BINAP-CMP-3D-2 & Ir/BINAP & \\
\hline$\overline{1}$ & $\mathrm{H} / \mathrm{Me}(\mathbf{1 a})$ & 99 & 24 & 70 & 72 & $R$ \\
\hline 2 & H/Et (1b) & 99 & 23 & 77 & 78 & $R$ \\
\hline 3 & $\mathrm{H} / n-\operatorname{Pr}(\mathbf{1 c})$ & 99 & 16 & 78 & 74 & $R$ \\
\hline 4 & $\mathrm{H} / n-\mathrm{Bu}(\mathbf{1 d})$ & 80 & 18 & 77 & 75 & $R$ \\
\hline 5 & $\mathrm{H} / i-\operatorname{Pr}(\mathbf{1 e})$ & 83 & 13 & 79 & 75 & $R$ \\
\hline 6 & $\mathrm{H} / \mathrm{Ph}(\mathbf{1 f})$ & 84 & 34 & 44 & 50 & $R$ \\
\hline 7 & $\mathrm{~F} / \mathrm{Me}(\mathbf{1 g})$ & 99 & 23 & 63 & 77 & $S$ \\
\hline 8 & $\mathrm{Me} / \mathrm{Me}(\mathbf{1 h})$ & 99 & 16 & 67 & 76 & $R$ \\
\hline 9 & $\mathrm{MeO} / \mathrm{Me}(\mathbf{1 i})$ & 97 & 9 & 70 & 78 & $R$ \\
\hline
\end{tabular}

Reaction conditions: quinoline $0.25 \mathrm{mmol}, \mathrm{CH}_{2} \mathrm{Cl}_{2} 3 \mathrm{~mL}$, [Ir(COD)Cl] $]_{2} 0.00125 \mathrm{mmol}, \mathrm{I}_{2} 0.05 \mathrm{mmol}, 4 \mathrm{MPa} \mathrm{H}_{2}, 25{ }^{\circ} \mathrm{C}, 2$ h. a,b See Table 1 . ${ }^{\mathrm{d}}$ The absolute configuration is assigned by comparison of the HPLC retention time with those reported in the literature data.

Table 5

Recycling experiment of the BINAP-CMP-3D-2 catalyst.

\begin{tabular}{lccccccc} 
& & & & \\
\cline { 2 - 8 }
\end{tabular}

Reaction conditions: quinaldine $0.5 \mathrm{mmol}, \mathrm{CH}_{2} \mathrm{Cl}_{2} 3 \mathrm{~mL}$, [Ir(COD)Cl $]_{2}$ $0.00125 \mathrm{mmol}, \mathrm{I}_{2} 0.05 \mathrm{mmol}, 4 \mathrm{MPa} \mathrm{H}, 25^{\circ} \mathrm{C}, 2 \mathrm{~h}$. a,b See Table 1.

dimmers by the spatial isolation effect of the CMP, the BINAP-CMPs gave much higher activity than the homogeneous BINAP ligand.

\section{References}

[1] Katritzky A R, Rachwal S, Rachwal B. Tetrahedron. 1996, 52: 15031

[2] Wang W B, Lu S M, Yang P Y, Han X W, Zhou Y G. J Am Chem Soc, 2003, 125: 10536
[3] Cai X F, Chen M W, Ye Z S, Guo R N, Shi L, Li Y Q, Zhou Y G. Chem Asian J, 2013, 8: 1381

[4] Lu S M, Han X W, Zhou Y G. Adv Synth Catal, 2004, 346: 909

[5] Wang D W, Wang X B, Wang D S, Lu S M, Zhou Y G, Li Y X. J Org Chem, 2009, 74: 2780

[6] Wang X B, Zhou Y G. J Org Chem, 2008, 73: 5640

[7] Zhang D Y, Wang D S, Wang M C, Yu C B, Gao K, Zhou Y G. Synthesis, 2011, (17): 2796

[8] Xu L K, Lam K H, Ji J X, Wu J, Fan Q H, Lo W H, Chan A S C. Chem Commun, 2005, (11): 1390

[9] Lam K H, Xu L J, Feng L C, Fan Q H, Lam F L, Lo W H, Chan A S C. Adv Synth Catal, 2005, 347: 1755

[10] Tang W J, Zhu S F, Xu L J, Zhou Q L, Fan Q H, Zhou H F, Lam K H, Chan A S C. Chem Commun, 2007, (6): 613

[11] Reetz M T, Li X G, Chem Commun, 2006, (20): 2159

[12] Blaser H U, Pugin B, Spindler F, Togni A. C R Chim, 2002, 5: 379

[13] Wang Z J, Deng G J, Li Y, He Y M, Tang W J, Fan Q H. Org Lett, 2007, 9: 1243

[14] Wang D S, Zhou J, Wang D W, Guo Y L, Zhou Y G. Tetrahedron Lett, 2010, 51: 525

[15] Wang X, Lu S M, Li J, Liu Y, Li C. Catal Sci Technol, 2015, 5: 2585

[16] Zhu Y N, Jiang Y J, Gao J, Zhou L Y, He Y, Jia F. Chin J Catal (朱亚男,

\section{Graphical Abstract}

Chin. J. Catal., 2015, 36: 1170-1174 doi: 10.1016/S1872-2067(15)60903-2

Efficient enantioselective hydrogenation of quinolines catalyzed by conjugated microporous polymers with embedded chiral BINAP ligand

Xu Wang, Jun Li, Shengmei Lu, Yan Liu*, Can Li*

Dalian Institute of Chemical Physics, Chinese Academy of Sciences;

University of Chinese Academy of Sciences

A series of chiral BINAP-CMPs with different surface areas were synthesized which were three times more active than the homogeneous BINAP catalyst (TOF $340 \mathrm{~h}^{-1}$ VS $100 \mathrm{~h}^{-1}$ ) for the asymmetric hydrogenation of quinolines.

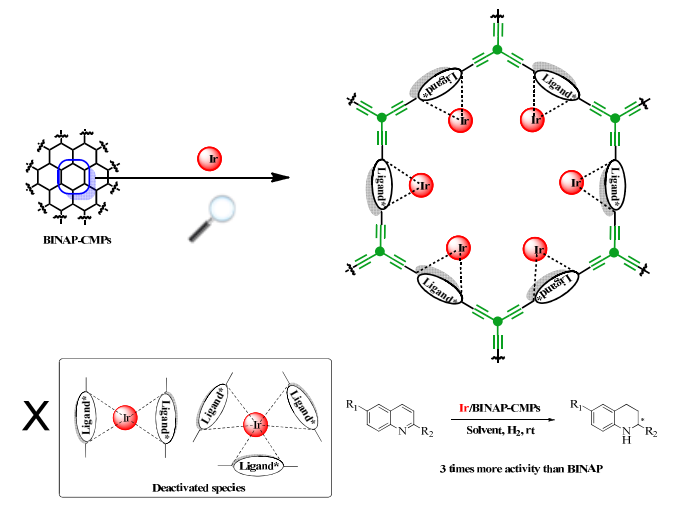


姜艳军, 高静, 周丽亚, 贺莹, 贾霏. 催化学报), 2013, 34: 741

[17] Li N, Du W Y, Huang Z N, Zhao W, Wang S J. Chin J Catal (李娜, 杜伟 燕, 黄卓楠, 赵炜, 王寿江. 催化学报), 2013, 34: 769
[18] Dong Y S, Liu L P, Bao Y M, Hao A Y, Qin Y, Wen Z J, Xiu Z L. Chin J Catal (董悦生, 刘乐平, 包永明, 郝爱鱼, 秦莹, 温祖佳, 修志龙. 催化学报), 2014, 35: 1534

\title{
含有手性BINAP基团的共轭微孔聚合材料应用于喹啉高效不对称氢化反应
}

\author{
王 旭 ${ }^{\mathrm{a}, \mathrm{b}}$, 李 军 ${ }^{\mathrm{a}, \mathrm{b}}$, 卢胜梅 ${ }^{\mathrm{a}, \mathrm{b}}$, 刘 䶮 ${ }^{\mathrm{a}, \mathrm{b}, *}$, 李 灿 ${ }^{\mathrm{a}, \mathrm{b}, \#}$ \\ a国科学院大连化学物理研究所, 辽宁大连 116023 \\ $\mathrm{b}$ 中国科学院大学, 北京 100049
}

摘要：喹啉不对称氢化反应是不对称氢化研究的重点之一. 其氢化产物四氢喹啉不仅是重要的有机合成中间体, 同时也是自然界 中生物碱的结构单元和生物活性化合物. 周永贵研究组首次报道了手性 $(R)-\mathrm{MeO}-\mathrm{Biphep} / \mathrm{Ir}$ 体系成功用于喹啉的不对称催化, 取得 了非常好的反应结果. 随后他们对喹啉底物进行了拓展, 包括拥有特殊取代基的喹啉衍生物, 均取得了良好的反应结果. 后来多 个研究组对该反应进行了深入研究并开发出了多个不同手性膦配体的Ir催化体系. 虽然喹啉不对称氢化反应取得了很大的发展, 但是该均相反应体系只能在高的反应催化剂用量下才能实现好的结果. 进一步研究发现手性配体与金属Ir络合后形成反应活性 物种, 但后者可发生二聚或三聚, 生成的产物是不具有催化活性的, 从而导致了反应体系需要高的催化剂的用量. 为此人们做了 大量研究. 范青华研究组通过对BINAP基团上嫁接大空间位阻的枝状分子合成了一系列新的手性BINAP配体, 在与Ir络合后, 表 现出远高于均相催化剂的反应活性, 且可循环利用. 在该体系中, 大位阻的枝状分子起到了阻隔活性物种二聚、三聚的作用, 因而 提高了反应活性. 后来周永贵研究组也尝试通过改变有机配体的方法来实现高的反应活性. 他们选择改变手性双膦配体上P原子 所连接有机配体的空间位阻来实现对活性物种多聚的控制. 实验同样取得了很好的反应效果. 对于均相反应体系, 我们只能通过 这种改变有机配体空间位阻的方式来降低活性物种多聚的可能性, 那么如何彻底阻止这种多聚呢? 非均相体系给我们提供了很 好的研究思路, 但如何将非均相体系引入到喹啉不对称氢化反应体系当中成为了难点.

共轭微孔聚合物(CMPs)的发展使得手性催化体系很容易从均相转变到非均相. 这种材料具有较高的比表面积和固定的开放 孔道结构, 可应用于非均相催化中. 且制备相对容易. 我们可以将手性双膦配体作为材料制备配体嫁接到CMPs材料当中. 在这 种材料当中, 手性配体会以有序、空间分离的方式分布, 在与Ir配合后应用于喹啉不对称氢化反应中, 从而从根本上避免了活性物 种多聚的可能因此反应活性提高. 我们曾首次成功合成了一系列含有手性 $(R)$-Binap基团的共轭微孔聚合材料-BINAP-CMPs, 并 将其用于 $\beta$-酮酸酯的不对称氢化反应当中, 取得了很好的催化效果. 手性BINAP基团均匀、有序地分散于该材料中. 我们尝试利 用BINAP-CMPs固有的空间隔离效应, 将其应用于喹啉的不对称氢化反应中, 结果表明, 在相同条件下, 非均相BINAP-CMPs/Ir催 化体系的TOF值是 $340 \mathrm{~h}^{-1}$, 是均相BINAP/Ir体系 $\left(100 \mathrm{~h}^{-1}\right)$ 3倍, 反应的对映体选择性与均相相当; 另外该催化体系多循环利用次后 仍可以保持高的反应活性. 我们还发现材料结构性质对反应结果的影响很大, 材料的比表面积和孔容更大反应结果更好.

关键词: 不对称氢化; 喹啉; BINAP; 共轭微孔聚合物; 空间分离效应

收稿日期: 2015-05-04. 接受日期：2015-05-21. 出版日期：2015-08-20.

*通讯联系人. 电话: (0411)84379302; 传真: ((0411)84694447; 电子信箱: yanliu503@dicp.ac.cn

\#通讯联系人. 电话: (0411)84379070; 传真: ((0411)84694447; 电子信箱: canli@dicp.ac.cn

基金来源: 国家自然科学基金(21322202).

本文的英文电子版由Elsevier出版社在ScienceDirect上出版(http://www.sciencedirect.com/science/journal/18722067). 